УДК 378:373.3.011.3-051=111

\title{
IMPROVEMENT OF PROFESSIONAL TRAINING OF RIMARY SCHOOL TEACHER IN THE SYSTEM OF HIGHER EDUCATION
}

Fentsyk Oksana

Фенцик О. М.

\section{УДОСКОНАЛЕННЯ ПРОФЕСІЙНОЇ ПІДГОТОВКИ ВЧИТЕЛЯ ПОЧАТКОВИХ КЛАСІВ У СИСТЕМІ ВИЩОЇ ОСВІТИ}

A certain contradiction between the needs for modernisation of modern elementary education in accordance with the conceptual foundations of the New Ukrainian school and the insufficient level of readiness of primary school teachers to innovate activity are being determined by the author in the present article. The urgency of training of professional and competent teacher is also indicated the article under consideration.

The article aims at investigating the directions of improving the training of a competently qualified primary school teacher in the higher education system.

In accordance with the purpose of the study, the method of theoretical analysis and synthesis has been used in the process of developing the research methodology; method of observation, conversation - to determine the state of readiness of primary school teachers to innovate; design method - to predict research prospects.

In the article, the author points out the importance of training a professionally competent teacher who is capable of designing, organising, evaluating, reflecting and adjusting the educational process in elementary school in accordance with modern requirements. Considers the directions of improvement of the training of a professionally competent teacher of elementary school in the system of institutions of higher education.

Summing up, the author notes that it is very necessary in pedagogical higher educational establishments to create such educational and scientific environment in which students independently model, construct, research, create effective educational projects.

Keywords: new Ukrainian school, professional training, professional competence, innovations, educational and scientific environment.

У статті автор зазначає, щзо існує певна суперечність між потребами модернізаиіі сучасної початкової освіти відповідно до концептуальних засад Нової української школи та недостатнім рівнем готовності вчителів початкової школи до здійснення інноваційної діяльності. Вказує на важливість підготовки професійно компетентного вчителя, який здатний до проектування, організаџії, оцінювання, рефлексії та коригування освітнього процесу в початковій школі відповідно до сучасних вимог. Розглядає напрями удосконалення підготовки професійно компетентного вчителя початкової загальноосвітньої школи в системі закладів вищої освіти.

Ключові слова: нова украӥнська школа, професійна підготовка, професійна компетентність, інновачї̈, навчально-наукове середовище.

In the process of improvement of national educational system ( «Development conception of Ukraine dating the years 2015-2025» [1], Conception «New Ukrainian school» [2]) attention has been drawn to the to the professional training of teaching staff of modern generation. Reformation of New Ukrainian school starts from primary education which encourages the scientists to proceed scientific discussion about the search for the concept of training of professionally competent primary school teacher in the system of higher educational establishment. Teachers-to-be should be 
capable to make projects, to organize, to assess and to correct educational process in primary school according to present-day requirements.

The analysis of scientific researches proves that the problem under consideration has been investigated by such scholars as: N. Bibik, L. Biriuk, O. Budnyk, M. Vashulenko, V. Davydova, L. Koval, L. Perminova, O. Savchenko, S. Skvortsova, L. Khomych, Y. Shapoval, V. Shpak and others. These works indicate the regularities and principles of professional training of future primary school teachers, determine pedagogical conditions of formation the readiness of future primary school teacher to person-oriented education of schoolchildren of junior schoolage.

One of the possible ways of improvement of educational process is supposed to be «implementation of innovative methods of study, establishment of educational institutions of new type» [1, c. 3]. But, we consider, that there is still contradiction between the needs of modernization of modern primary education based on innovations and unsufficient level of readiness of primary school teachers to innovative activity.

Aim of the article - determine the ways of training improvement of professional and competent primary school teacher in the system of higher education.

Educational model which has been existing till nowadays and has been directed onto the knowledge and skills transmission is losing its urgency. Nowadays a teacher is required not only "to instuct", but "to train" which becomes social and professional demand in the context of education. According to the book of Philip S. Shlekhti «School of XXI century. Prioroties of education reforming», school requires teachers, who are able to teach a pupil to work with a book, search for and get information, obtain knowledge from a teacher, to be capable to communicate in the process of education. Teachers can meet such requirements only by studying themselves in the same analogical way. [3, p.121].

Domineering point of the modern educational paradigm is orientation onto the training of a teacher, which is directed to creative self-realization, self-development, formation of fundamentals of professional competence and self-realization during a life-time. According to O.Savchenko, the professional competence of a teacher is an integrated result of acquiring by the personality knowledge, skills, individual experience, professional activity, which is based on values and motivational benchmarks that are manifested in behavior and reflection. Competence does not only synthesize the results of conscientious and systematic training in the class-room while cooperating with the teacher, but also presupposes self-education, life experience, attitude to the future profession [4, p.19].

L.V. Koval, considering the concepts of didactic and methodological system of training future teachers to implementation of general educational technologies of primary school, which is based on systemic, personal and activity, competence and technological approaches; defines technological competence as the basic criterion of readiness of future primary school teachers to implementation of general educational innovative technologies [5].

Pedagogical higher educational establishments should pay special attention to training primary school teachers in innovate activity. In the process of introducing innovations to a creative teacher (taking into consideration that the present times require a creative teacher), the goal arises to find new unconventional approaches in organizing educational process and not only to implement but also to create new technology of training and education which effectively implement the requirements of personality oriented and competently directed educational sphere. It is therefore necessary to create educational system aimed at training future teachers to innovation, technological mastery and pedagogical skills.

The study at a higher educational institution should be oriented on the strengthening of fundamental didactic and methodological education, the approaching of the educational process to creative professional activities, to be directed towards the formation of a teacher's personality with the qualities that would meet modern requirements and ensure the success of pedagogical activity. Therefore, it is necessary to provide high-quality didactic and methodical training of the future teacher, who can reasonably choose methods, techniques, means, forms of organization of study 
according to peculiarities of pupils in class; who is capable to introduce the latest techniques and technologies of educational branches into the educational process.

The driving force of the optimization and intensification of the future teacher's training process is making up of an innovative educational environment for higher pedagogical establishment, its focus on a total combination of scientific and educational work of students, the closest approach of the educational process to creative activity, the formation of such personality traits that would ensure successful implementation in the profession of a teacher. It is necessary to create a new approach to study as the organization of educational, research, gaming, modeling activities; active exchange of ideas, creative discussion. It is extremely important in pedagogical universities to provide such educational and scientific atmosphere that would facilitate the use of acquired knowledge and experience in different situations, introduce role and imitation modeling, creative search.

The present-day student of pedagogical university should freely orient himself in pedagogical innovations, to be able to use the means of information and communication technologies, to understand deeply the needs and conditions of the functioning of primary education. Such an approach to professional training will enable a young teacher to feel confident in professional activity, to adapt more quickly to the conditions of a present-day school, to solve successfully complex tasks of educational work, to be able to study personal qualities, peculiarities of students, to determine optimal conditions of pedagogical influence, to analyze results of their own activities, etc.

The process of modernization of system of training of primary school teacher presupposes of making up optimal pedagogical conditions, the most improtant of which are: psychological and pedagogical readiness not only teachers but also students to implementation of innovative methods into educational process; arrengement of educational process according to the dialogue principle, partnership and orientation on the development of personal and professional qualities of students; creation of the situation of success in academic activity; activization of students to impulsive motives of creative self-expression; rational use of traditional and innovative educational technologies, modern methods of education; work out of the complex of diagnostic methods of students' academic success.

The following tendencies of improvement of professional training of primary school teacher can be singled out: active implementation of interactive forms in teaching students; the use of practically oriented appoach in professional training of teachers, which will support the closest approximation to the future professional activity during the university study; the work out of individual programs of personal and professional development of gifted students; the increasement of the role of students' research and independent work; improvement of content of curriculum and academic programs; reforming of pedagogical practice according to the European experience .

Summing up information mentioned above, it is worth indicating, that strategic tasks of higher pedagogical establishments include: training of competent professional, who is able to act effectively far off the educational situations, to solve typical and problem tasks in their own professional activities, to apply problem, heuristic, research methods of teaching, to be capable to create an educational and problem dialogue, to encourage students to exchange their thoughts and impressions fluently, to form critical thinking and creative abilities of schoolchildren. Therefore, it is necessary to create such educational and scientific environment where students would independently model, construct, explore, make up educational projects.

The carried out investigation does not totally describe the problem of the formation of professional competence in the training of primary school teachers in the system of higher education. The further scientific researches of the author is the study of the model of the formation of philological and methodical competence as the readiness and ability of future teachers of primary school to the study of language and literary education. 


\section{Список використаних джерел}

1. Проект Концепції розвитку освіти України на період 2015-2025 років [Електронний pecypc]. - Режим доступу: http://education-ua.org/ru/draft-regulations/319-proekt-kontseptsiyarozvitku-osviti-ukrajini-na-period-2015-2025-rokiv

2. Нова українська школа. Концептуальні засади реформування середньої школи. [Електронний ресурс]. - Режим доступу: http://nus.org.ua/wp-content/ uploads/2017/07/ konczepcziya.pdf

3. Phillip, C. Schlechty Schoolsforthe 21st Century. Leadershipimperativesfor Education Reform / C. Phillip. - SanFrancisco,1990. - 164 p.

4. Савченко О. Я. Компетентнісний підхід як чинник якості професійної підготовки майбутнього вчителя / О. Я. Савченко //Формування ключових i предметних компетентностей молодших школярів: теоретичні аспекти. Науково-методичний збірник. Серія «Бібліотека педагога». Випуск 20. - С. 15-21.

5. Коваль Л. В. Підготовка майбутніх учителів до застосування загально-навчальних технологій у початковій школі: штрихи концепції / Л. В. Коваль // Наукові записки Тернопільського національного педагогічного університету імені Володимира Гнатюка. Серія : Педагогіка. - 2010. - № 3. - С. 48 - 53.

\section{References}

1. Proekt Kontseptsii rozvytku osvity Ukrainynaperiod 2015-2025 rokiv [Draft of the Concept for the Development of Ukrainian Education for the period 2015-2025], 2014. Available at: http://education-ua.org/ru/draft-regulations/319-proekt-kontseptsiya-rozvitku-osviti-ukrajini-naperiod-2015-2025-rokiv [Accessed: 29 march 2018]

2. Nova ukrainska shkola. Kontseptualni zasady reformuvannia serednoi shkoly [New Ukrainian School. Conceptual Principles of High School Reforming], 2016. Available at: http://nus.org.ua/wp-content/uploads/2017/07/konczepcziya.pdf [Accessed: 29 march 2018]

3. Phillip, C. Schlechty (1990), Schoolsforthe 21st Century. Leadership imperatives for Education Reform, San Francisco, 164 p.

4. Savchenko, O.Y. (2012), Kompetentnisnyi pidkhid yak chynnyk yakosti profesiinoi pidhotovky maibutnoho vchytelia [Competency approaches a factor in the quality of the future teacher's professional training], Formuvanni akliuchovykh i predmetnykh kompetentnostei molodshykh shkoliariv: teoretychni aspekty. Naukovo-metodychnyi zbirnyk, Series «Biblioteka pedahoha», Release 20, pp. 15-21.

5. Koval, L.V. (2010), Pidhotovka maibutnikh uchyteliv do zastosuvannia zahalnonavchalnykh tekhnolohii u pochatkovii shkoli: shtrykhy kontseptsii [Preparation of future teachers for the application of general education technologies in elementary school: the strokes of the concept], Naukovi zapysky Ternopilskoho natsionalnoho pedahohichnoho universytetu imeni Volodymyra Hnatiuka, Serie : Pedahohika, № 3, pp. 48-53 